\title{
Cytotoxic potential of selected medicinal plants in northeast Brazil
}

Thiago B. C. da Silva', Cinara O. D'Sousa Costa², Alexandre F. C. Galvão², Larissa M. Bomfim², Ana Carolina B. da C. Rodrigues², Mauricio C. S. Mota', Alex A. Dantas' ${ }^{1}$, Tiago R. dos Santos ${ }^{1}$, Milena B. P. Soares ${ }^{2,3}$ and Daniel P. Bezerra ${ }^{2 *}$

\begin{abstract}
Background: Great biodiversity is a highlight of Brazilian flora. In contrast, the therapeutic potentialities of most species used in folk medicine remain unknown. Several of these species are commonly used to treat cancer. In this study, we investigated the cytotoxic activity of 18 plants from 16 families that are found in the northeast region of Brazil.

Methods: The following species were studied: Byrsonima sericea DC. (Malpighiaceae), Cupania impressinervia Acev. Rodr. var. (revoluta) Radlk (Sapindaceae), Duranta repens Linn. (Verbenaceae), Helicostylis tomentosa (Poepp. \& Endl) Rusby (Moraceae), Himatanthus bracteatus (A.DC.) Woodson (Apocynaceae), Ipomoea purga (Wender.) Hayne (Convolvulaceae), Ixora coccinea Linn. (Rubiaceae), Mabea piriri Aubl. (Euphorbiaceae), Miconia minutiflora (Melastomataceae), Momordica charantia L. (Cucurbitaceae), Ocotea glomerata (Nees) Mez (Lauraceae), Ocotea longifolia Kunth (Oreodaphne opifera Mart. Nees) (Lauraceae), Pavonia fruticosa (Mill.) Fawc. \& Rendle (Malvaceae), Psychotria capitata Ruiz \& Pav. (Rubiaceae), Schefflera morototoni (Aubl.) Maguire, Steyerm. \& Frodin (Araliaceae), Solanum paludosum Moric. (Solanaceae), Xylopia frutescens Aubl. (Annonaceae) and Zanthoxylum rhoifolium Lam. (Rutaceae). Their dried leaves, stems, flowers or fruits were submitted to different solvent extractions, resulting in 55 extracts. After incubating for $72 \mathrm{~h}$, the cytotoxicity of each extract was tested against tumor cell lines using the alamar blue assay.
\end{abstract}

Results: The B. sericea, D. repens, H. bracteatus, I. purga, I. coccinea, M. piriri, O. longifolia and P. capitata extracts demonstrated the most potent cytotoxic activity. The chloroform soluble fractions of $D$. repens flowers and the hexane extract of I. coccinea flowers led to the isolation of quercetin and a mixture of $a$ - and $\beta$-amyrin, respectively, and quercetin showed moderate cytotoxic activity.

Conclusion: The B. sericea, D. repens, H. bracteatus, I. purga, I. coccinea, M. piriri, O. Iongifolia and P. capitata plants were identified as having potent cytotoxic effects. Further investigations are required to determine the mechanisms of cytotoxicity exhibited and their in vivo activities. This work reinforces the need to understand the therapeutics potentialities of Brazilian medicinal plants.

Keywords: Cytotoxicity, Northeastern Brazil, Medicinal plants, Natural products

\footnotetext{
* Correspondence: danielpbezerra@gmail.com

${ }^{2}$ Instituto Gonçalo Moniz, Fundação Oswaldo Cruz (IGM/FIOCRUZ-BA), Rua

Waldemar Falcão, 121, Candeal, 40296-710 Salvador, Bahia, Brazil

Full list of author information is available at the end of the article
} 


\section{Background}

In Brazil, the estimated number of described plant species (terrestrial and algae) ranges from 50,542 to 60,042 [1]; they are found in the following six different biomes: Amazônia (the Amazon rainforest in northern and central-western Brazil), Cerrado (the central Brazilian savanna), Mata Atlântica (the Atlantic rainforest ranging from sea level to the eastern highlands of Brazil), Caatinga (a xerophilous thorny forest found in northeastern Brazil), Pampa (the grasslands in southern Brazil) and Pantanal (periodically flooded grasslands by the Paraná and Paraguay rivers in central-western Brazil). Thus, Brazil is one of the most biodiverse nations in the world [1-3].

The cytotoxic potential of some Brazilian medicinal plants has been previously investigated [4-7]; however, due to the country's great biodiversity, the therapeutic potentialities of most species remain unknown. In this work, the cytotoxic activities of 18 plants belonging to 16 families found in northeast Brazil were assessed against tumor cell lines. The following species were studied: Byrsonima sericea DC. (Malpighiaceae), Cupania impressinervia Acev. Rodr. var. (revoluta) Radlk (Sapindaceae), Duranta repens Linn. (Verbenaceae), Helicostylis tomentosa (Poepp. \& Endl) Rusby (Moraceae), Himatanthus bracteatus (A.DC.) Woodson (Apocynaceae), Ipomoea purga (Wender.) Hayne (Convolvulaceae), Ixora coccinea Linn. (Rubiaceae), Mabea piriri Aubl. (Euphorbiaceae), Miconia minutiflora (Melastomataceae), Momordica charantia L. (Cucurbitaceae), Ocotea glomerata (Nees) Mez (Lauraceae), Ocotea longifolia Kunth (Oreodaphne opifera Mart. Nees) (Lauraceae), Pavonia fruticosa (Mill.) Fawc. \& Rendle (Malvaceae), Psychotria capitata Ruiz \& Pav. (Rubiaceae), Schefflera morototoni (Aubl.) Maguire, Steyerm. \& Frodin (Araliaceae), Solanum paludosum Moric. (Solanaceae), Xylopia frutescens Aubl. (Annonaceae) and Zanthoxylum rhoifolium Lam. (Rutaceae). The plant species, family, vernacular name and traditional use in Brazil are shown in Table 1.

\section{Methods}

\section{Plant material}

Leaves, stems, fruits and/or flowers of B. sericea (voucher number 45628), C. impressinervia (voucher number 42953), D. repens (voucher number 25870), H. tomentosa (voucher number 20586), H. bracteatus (voucher number 50733), I. purga (voucher number 33255) and $I$. coccinea (voucher number 25861) were collected in February 2014 in the Municipality of Viçosa, Alagoas, Brazil. Leaves and/or stems of $M$. piriri (voucher number 45717), M. minutiflora (voucher number 49653), $M$. charantia (voucher number 34393), O. glomerata (voucher number 50577), O. longifolia (voucher number 50577), $P$. fruticosa (voucher number 45659) and $P$. capitata (voucher number 45620) were collected in March 2014 in the municipality of Rio Largo, Alagoas, Brazil. Leaves, stems and/or fruits of S. morototoni (voucher number 45659), S. paludosum (voucher number 37400), $X$. frutescens (voucher number 45677) and $Z$. rhoifolium (voucher number 49656) were collected in March 2014 in the Municipality of Murici, Alagoas, Brazil. All plants were collected in the Mata Atlântica bioma. The species were identified by Rosângela Pereira e Lyra Lemos, a plant taxonomist from the Instituto do Meio Ambiente de Alagoas IMA-AL. Voucher botanical specimens are stored at the Herbarium of the Instituto do Meio Ambiente de Alagoas IMA-AL. This work was performed according to the special authorization for access to genetic resources in Brazil \# 010344/2014-4, issued by $\mathrm{CNPq} / \mathrm{MCTI}$.

\section{Plant extractions}

The dried leaves, stems, flowers or fruits were triturated and extracted at room temperature with ethanol or hexane. The solvent was removed to produce the correspondent crude extracts. The extraction steps for each sample were repeated three times with one-week intervals. Part of leaves, fruits or flowers ethanol extract was suspended in methanol:water (9:1) solution and extracted successively with ethyl acetate, chloroform, hexane or hexane:ethyl acetate (1:1) to produce the corresponding partitioned extracts.

\section{Chemical fractionation \\ General procedures}

Purification processes were performed through column chromatography (CC) using silica gel $60 \quad(0.063-$ $0.200 \mathrm{~mm}$ ) as the stationary phase. Organic solvents or mixtures of increasing polarity were used as mobile phases. Silica gel 60 GF (Merck, Darmstadt, Germany) was used to perform analytical $(0.25 \mathrm{~mm})$ or preparative $(0.75 \mathrm{~mm})$ thin layer chromatographic (TLC) processes.

The ${ }^{1} \mathrm{H}(400 \mathrm{MHz})$ and ${ }^{13} \mathrm{C}(100 \mathrm{MHz})$ nuclear magnetic resonance (NMR) spectra were obtained on a Bruker Avance DRX-400 spectrometer (Bruker, Rheinstetten, Germany), operating at $300 \mathrm{~K}$. The chemical shifts $(\delta)$ were expressed in units of $\mathrm{ppm}$, using tetramethylsilane (TMS) as a reference $\left(\delta_{\mathrm{H}}=\delta_{\mathrm{c}}=0\right)$, and the coupling constants $(J)$ were expressed in $\mathrm{Hz}$. Chloroform-d was used as the solvent for the samples.

\section{Isolation of compounds}

The chloroform extract of $D$. repens flowers $(7 \mathrm{~g})$ was submitted to silica gel CC eluted with hexane and ethyl acetate (either pure or a mixture of increasing polarity), providing 50 fractions $(5 \mathrm{~mL}$ each) that were grouped with hexane and ethyl acetate. After solvent evaporation, fractions 30-50 were purified with Sephadex-L 
Table 1 List of plants and their vernacular name and folk use in Brazil

\begin{tabular}{|c|c|c|c|}
\hline Plant species & Family & Vernacular name & Folk use in Brazil \\
\hline Byrsonima sericea DC. & Malpighiaceae & Murici-da-mata & $\begin{array}{l}\text { A decoction of the stem-bark is used to treat fevers, diarrhea, } \\
\text { syphilis and kidney disease [26] }\end{array}$ \\
\hline $\begin{array}{l}\text { Cupania impressinervia Acev. } \\
\text { Rodr. var. (revoluta) Radlk }\end{array}$ & Sapindaceae & Caboatã-de-rego & - \\
\hline Duranta repens Linn. & Verbenaceae & Pingo-de-ouro & Ornamental [27] \\
\hline $\begin{array}{l}\text { Helicostylis tomentosa (Poepp. } \\
\text { \& Endl) Rusby }\end{array}$ & Moraceae & Amoreira-preta & Its fruit is used as a nutritional source [28] \\
\hline $\begin{array}{l}\text { Himatanthus bracteatus } \\
\text { (A.DC.) Woodson }\end{array}$ & Apocynaceae & Janaguba & $\begin{array}{l}\text { The latex is topically applied to treat external ulcers and tumors. It is } \\
\text { dropped in a liter of water against inflammation and cancer [26] }\end{array}$ \\
\hline $\begin{array}{l}\text { Ipomoea purga (Wender.) } \\
\text { Hayne }\end{array}$ & Convolvulaceae & Jalapa, batata-de-purga & It is used as an analgesic [29] \\
\hline Ixora coccinea Linn. & Rubiaceae & Ixora & Ornamental [30] \\
\hline Mabea piriri Aubl. & Euphorbiaceae & Canudo de cachimbo & - \\
\hline Miconia minutiflora & Melastomataceae & Mundururu & Its fruit is used as a nutritional source [28] \\
\hline Momordica charantia L. & Cucurbitaceae & $\begin{array}{l}\text { Melão-de-sabiá, melão-de- } \\
\text { são-caetano, galinha-de- } \\
\text { melão }\end{array}$ & $\begin{array}{l}\text { A decoction of a handful in a liter of water is used as a tea to treat } \\
\text { diabetes, parasite infections, rheumatism and diarrhea [26] }\end{array}$ \\
\hline Ocotea glomerata (Nees) Mez & Lauraceae & $\begin{array}{l}\text { Caneleira, louro-branco, } \\
\text { louro-abacate, louro-bravo }\end{array}$ & $\begin{array}{l}\text { The leaves are used to treat hydropsy, digestive problems and high } \\
\text { blood pressure }[31,32]\end{array}$ \\
\hline $\begin{array}{l}\text { Ocotea longifolia Kunth } \\
\text { (Oreodaphne opifera Mart. } \\
\text { Nees) }\end{array}$ & Lauraceae & Canela de cheiro & Fruit oil is used to treat arthralgia and rheumatic diseases [33] \\
\hline $\begin{array}{l}\text { Pavonia fruticosa (Mill.) Fawc. } \\
\text { \& Rendle }\end{array}$ & Malvaceae & - & - \\
\hline Psychotria capitata Ruiz \& Pav. & Rubiaceae & - & - \\
\hline $\begin{array}{l}\text { Schefflera morototoni (Aubl.) } \\
\text { Maguire, Steyerm. \& Frodin }\end{array}$ & Araliaceae & Matatauba, Marupá & Its fruit is used as a nutritional source and to make local crafts [28] \\
\hline Solanum paludosum Moric. & Solanaceae & $\begin{array}{l}\text { Jurubeba-brava, jurubeba- } \\
\text { roxa }\end{array}$ & $\begin{array}{l}\text { An infusion of the roots is used to treat hepatic diseases. The fruit is } \\
\text { used as a poison [26] }\end{array}$ \\
\hline Xylopia frutescens Aubl. & Annonaceae & $\begin{array}{l}\text { Embira, semente-de- } \\
\text { embira }\end{array}$ & $\begin{array}{l}\text { Its seeds and fruits are used as a digestive aid (a decoction of a } \\
\text { teaspoon in a cup of water). It is used as a tea after meals [26] }\end{array}$ \\
\hline Zanthoxylum rhoifolium Lam. & Rutaceae & $\begin{array}{l}\text { Mamica de cadela, mamica } \\
\text { de porca }\end{array}$ & $\begin{array}{l}\text { The roots are used as a febrifuge, digestant and tonic. The stem bark } \\
\text { is used to treat flatulence, colic, dyspepsia, ear aches, toothaches and } \\
\text { snake bites [34] }\end{array}$ \\
\hline
\end{tabular}

water:methanol, yielding the compound quercetin $(56,11.0 \mathrm{mg})$. The compound structure was identified through a series of spectrometric data, such as NMR, as well as by comparison with data reported in the literature.

A hexane extract of I. coccinea flowers (26 g) was submitted to silica gel $\mathrm{CC}$ eluted with hexane, ethyl acetate and methanol (either pure or a mixture of increasing polarity), providing 100 fractions $(5 \mathrm{~mL}$ each) that were grouped with hexane, ethyl acetate and methanol. After solvent evaporation from fractions 30 to 45 (eluted with hexane/ethyl acetate 8:2), a white solid (in the form of flakes) was obtained (57, $14.0 \mathrm{mg}$ ). This solid was identified as a mixture of $\alpha$ and $\beta$-amyrin. The compounds structures were identified through a series of spectrometric data, such as NMR, as well as by comparison with data reported in the literature.

\section{Cells}

Tumor cells lines B16-F10 (mouse melanoma), HepG2 (human hepatocellular carcinoma), K562 (human chronic myelocytic leukemia) and HL-60 (human promyelocytic leukemia) were donated by the Hospital A.C. Camargo, São Paulo, SP, Brazil. This panel of cell lines include different types of cell histology with different sensibility. Cells were maintained in Roswell Park Memorial Institute-1640 (RPMI-1640, Gibco-BRL, Gaithersburg, USA) medium supplemented with $10 \%$ fetal bovine serum (Cultilab, Campinas, Brazil), $2 \mathrm{mM} \mathrm{L}$-glutamine (Vetec Química Fina, Duque de Caxias, Brazil) and $50 \mu \mathrm{g} / \mathrm{mL}$ gentamycin (Novafarma, Anápolis, Brazil). Adherent cells were harvested by treatment with $0.25 \%$ trypsin EDTA solution (Gibco-BRL, Gaithersburg, USA). All cell lines were cultured in cell culture flasks at $37{ }^{\circ} \mathrm{C}$ in $5 \% \mathrm{CO}_{2}$ and sub-cultured every $3-4$ days to maintain exponential growth. All experiments were conducted 
Table 2 Growth inhibitory effects of plant extracts/fractions against tumor cell lines

\begin{tabular}{|c|c|c|c|c|}
\hline \multirow[t]{2}{*}{ No. } & \multirow[t]{2}{*}{ Plant species } & \multirow{2}{*}{$\begin{array}{l}\text { Parts of the plant }{ }^{\mathrm{a}} \\
\text { (Extractions }^{\mathrm{b}} \text { ) }\end{array}$} & \multicolumn{2}{|c|}{ Cell $^{\complement}$ growth inhibition percentage $(\mathrm{Gl} \%)^{\complement}$} \\
\hline & & & HepG2 & HL60 \\
\hline 01 & \multirow[t]{7}{*}{ Byrsonima sericea DC. } & $\mathrm{F}(\mathrm{e})$ & $25.03 \pm 5.24$ & $25.27 \pm 8.79$ \\
\hline 02 & & $S(e)$ & $8.02 \pm 6.85$ & $27.32 \pm 0.06$ \\
\hline 03 & & $\mathrm{~L}(\mathrm{e})$ & $21.84 \pm 2.64$ & $64.71 \pm 5.28$ \\
\hline 04 & & $\mathrm{~L}(\mathrm{~m} / \mathrm{e})$ & $91.16 \pm 0.64$ & $102.7 \pm 1.12$ \\
\hline 05 & & L (ea/e) & $92.14 \pm 0.64$ & $103.3 \pm 7.26$ \\
\hline 06 & & $L(c / e)$ & $39.96 \pm 9.49$ & $70.12 \pm 11.24$ \\
\hline 07 & & $L(h / e)$ & $91.62 \pm 0.39$ & $109.0 \pm 2.52$ \\
\hline 08 & Cupania impressinervia Acev. Rodr. var. (revoluta) Radlk & $L(e)$ & $23.10 \pm 5.59$ & $55.19 \pm 5.50$ \\
\hline 09 & \multirow[t]{3}{*}{ Duranta repens Linn. } & $\mathrm{FL}(\mathrm{m} / \mathrm{e})$ & $14.09 \pm 7.14$ & $33.3 \pm 0.92$ \\
\hline 10 & & FL (ea/e) & $20.57 \pm 7.67$ & $28.36 \pm 0.46$ \\
\hline 11 & & $\mathrm{FL}(\mathrm{c} / \mathrm{e})$ & $79.94 \pm 2.97$ & $98.67 \pm 6.35$ \\
\hline 12 & \multirow[t]{2}{*}{ Helicostylis tomentosa (Poepp. \& Endl) Rusby } & $S(e)$ & $14.55 \pm 3.30$ & $53.67 \pm 0,58$ \\
\hline 13 & & $L(e)$ & $7.96 \pm 3.56$ & $38.39 \pm 7.33$ \\
\hline 14 & \multirow[t]{6}{*}{ Himatanthus bracteatus (A.DC.) Woodson } & $S(e)$ & $20.55 \pm 1.61$ & $29.38 \pm 1.63$ \\
\hline 15 & & $\mathrm{~L}(\mathrm{e})$ & $-9.90 \pm 6.56$ & $-16.91 \pm 4.61$ \\
\hline 16 & & $L(h)$ & $14.78 \pm 5.22$ & $70.63 \pm 2.62$ \\
\hline 17 & & $L(\mathrm{~m} / \mathrm{e})$ & $-0.77 \pm 2.61$ & $28.55 \pm 3.25$ \\
\hline 18 & & $\mathrm{~L}(\mathrm{ea} / \mathrm{e})$ & $5.70 \pm 2.61$ & $56.16 \pm 9.49$ \\
\hline 19 & & $L(c / e)$ & $92.30 \pm 1.50$ & $93.63 \pm 0.30$ \\
\hline 20 & \multirow[t]{2}{*}{ Ipomoea purga (Wender.) Hayne } & $S(e)$ & $98.39 \pm 1.81$ & $95.58 \pm 1.33$ \\
\hline 21 & & $L(e)$ & $93.86 \pm 2.70$ & $106.4 \pm 3.62$ \\
\hline 22 & \multirow[t]{7}{*}{ Ixora coccinea Linn. } & $\mathrm{F}(\mathrm{e})$ & $-2.97 \pm 9.22$ & $1.27 \pm 3.86$ \\
\hline 23 & & $\mathrm{FL}(\mathrm{h})$ & $21.47 \pm 5.44$ & $-25.64 \pm 9.33$ \\
\hline 24 & & $\mathrm{~L}(\mathrm{~m} / \mathrm{e})$ & $9.25 \pm 4.73$ & $1.38 \pm 1.35$ \\
\hline 25 & & $\mathrm{~L}(\mathrm{ea} / \mathrm{e})$ & $7.49 \pm 5.16$ & $32.25 \pm 9.39$ \\
\hline 26 & & L (h/e) & $22.55 \pm 3.23$ & $58.78 \pm 1.34$ \\
\hline 27 & & $\mathrm{~F}(\mathrm{ea} / \mathrm{e})$ & $-5.53 \pm 7.07$ & $18.83 \pm 5.74$ \\
\hline 28 & & $\mathrm{~F}(\mathrm{c} / \mathrm{e})$ & $94.93 \pm 0.74$ & $92.97 \pm 2.39$ \\
\hline 29 & \multirow[t]{2}{*}{ Mabea piriri Aubl. } & $\mathrm{S}(\mathrm{e})$ & $81.41 \pm 8.27$ & $92.35 \pm 7.66$ \\
\hline 30 & & $L(e)$ & $12.48 \pm 5.12$ & $69.56 \pm 0.17$ \\
\hline 31 & \multirow[t]{2}{*}{ Miconia minutiflora } & $S(e)$ & $25.64 \pm 6.34$ & $38.17 \pm 1.16$ \\
\hline 32 & & $L(e)$ & $38.62 \pm 2.72$ & $66.54 \pm 0.85$ \\
\hline 33 & Momordica charantia L. & $L(e)$ & $-17.51 \pm 2.97$ & $9.30 \pm 5.64$ \\
\hline 34 & \multirow[t]{2}{*}{ Ocotea glomerata (Nees) Mez } & $\mathrm{S}(\mathrm{e})$ & $49.49 \pm 9.87$ & $32.70 \pm 9.32$ \\
\hline 35 & & $L(c / e)$ & $25.48 \pm 7.87$ & $52.0 \pm 3.12$ \\
\hline 36 & \multirow[t]{2}{*}{ Ocotea longifolia Kunth (Oreodaphne opifera Mart. Nees) } & $S(e)$ & $-7.43 \pm 5.88$ & $2.49 \pm 0.33$ \\
\hline 37 & & $L(e)$ & $93.88 \pm 2.12$ & $94.70 \pm 1.06$ \\
\hline 38 & \multirow[t]{2}{*}{ Pavonia fruticosa (Mill.) Fawc. \& Rendle } & $S(e)$ & $44.81 \pm 1.66$ & $41.65 \pm 6.51$ \\
\hline 39 & & $L(e)$ & $33.34 \pm 4.48$ & $55.82 \pm 4.66$ \\
\hline 40 & \multirow[t]{4}{*}{ Psychotria capitata Ruiz \& Pav. } & $S(e)$ & $15.82 \pm 3.12$ & $64.16 \pm 0.32$ \\
\hline 41 & & L (e) & $28.13 \pm 8.45$ & $22.00 \pm 5.92$ \\
\hline 42 & & $\mathrm{~L}(\mathrm{~m} / \mathrm{e})$ & $19.16 \pm 8.90$ & $51.72 \pm 4.86$ \\
\hline 43 & & $L(e a / e)$ & $95.14 \pm 1.83$ & $86.55 \pm 4.20$ \\
\hline
\end{tabular}


Table 2 Growth inhibitory effects of plant extracts/fractions against tumor cell lines (Continued)

\begin{tabular}{|c|c|c|c|c|}
\hline 44 & & L (c/e) & $96.92 \pm 1.68$ & $92.87 \pm 0.06$ \\
\hline 45 & & $L(h / e)$ & $12.28 \pm 4.71$ & $-26.37 \pm 1.89$ \\
\hline 46 & & L (h:ea/e) & $61.84 \pm 9.74$ & $48.62 \pm 1.18$ \\
\hline 47 & \multirow[t]{2}{*}{ Schefflera morototoni (Aubl.) Maguire, Steyerm. \& Frodin } & $S(e)$ & $42.73 \pm 1.59$ & $-23.89 \pm 3.53$ \\
\hline 48 & & $L(e)$ & $9.05 \pm 7.07$ & $63.74 \pm 8.13$ \\
\hline 49 & Solanum paludosum Moric. & $\mathrm{S}(\mathrm{e})$ & $17.69 \pm 5.22$ & $63.81 \pm 2.08$ \\
\hline 50 & \multirow[t]{5}{*}{ Xylopia frutescens Aubl. } & $S(e)$ & $19.36 \pm 3.74$ & $72.39 \pm 2.90$ \\
\hline 51 & & $L(\mathrm{~m} / \mathrm{e})$ & $29.88 \pm 2.90$ & $18.19 \pm 6.52$ \\
\hline 52 & & L (ea/e) & $19.46 \pm 7.46$ & $51.24 \pm 5.86$ \\
\hline 53 & & $\mathrm{~L}(\mathrm{c} / \mathrm{e})$ & $71.00 \pm 3.06$ & $62.71 \pm 4.30$ \\
\hline 54 & & L (h/e) & $23.49 \pm 3.57$ & $69.41 \pm 0.88$ \\
\hline \multirow[t]{2}{*}{55} & Zanthoxylum rhoifolium Lam. & $\mathrm{L}(\mathrm{e})$ & $15.53 \pm 5.03$ & $14.00 \pm 4.00$ \\
\hline & Doxorubicin $^{e}$ & & $85.20 \pm 0.78$ & $86.34 \pm 2.27$ \\
\hline
\end{tabular}

\footnotetext{
${ }^{a}$ Parts of the plant: $L$ leaves, $S$ stem, $F$ Fruits, $F L$ flowers

bextractions: $h$ hexane, $m$ methanol, e ethanol, $m / e$ methanol/water partition from the ethanolic extract, ea/e ethyl acetate partition from the ethanolic extract, $h / e$ hexane partition from the ethanolic extract, c/e chloroform partition from the ethanolic extract, $h: e a / e$, hexane:ethyl acetate (1:1) partition from the ethanolic extract

'Cell lines: HepG2 (human hepatocellular carcinoma) and HL60 (human promyelocytic leukemia)

${ }^{\mathrm{d}} \mathrm{Gl} \%$ values are presented as the mean \pm S.E.M. of two independents experiment performed in triplicate measured by the alamar blue assay after $72 \mathrm{~h}$ incubation. All extracts were tested at a concentration of $50 \mu \mathrm{g} / \mathrm{mL}$. The negative control received the vehicle used to dilute the tested samples (0.5 \% DMSO)

${ }^{\mathrm{e}}$ Doxorubicin was used as the positive control
}

with cells in the exponential growth phase. All cell lines were tested for mycoplasma with a Mycoplasma Stain Kit (Sigma-Aldrich, St Louis, MO, USA) and found to be free from contamination.

Heparinized blood (from healthy, 20- to 35-year-old, non-smoking donors who had not taken any drug for at least 15 days prior to the sampling) was collected, and peripheral blood mononuclear cells (PBMC) were isolated using a standard protocol, with Ficoll (Ficoll-Paque Plus, GE Healthcare Bio-Sciences AB, Sweden) density gradient centrifugation. $\mathrm{PBMC}$ were washed and resuspended at a concentration of $0.3 \times 10^{6}$ cells $/ \mathrm{mL}$ in RPMI 1640 medium supplemented with $20 \%$ fetal bovine serum, $2 \mathrm{mM}$ L-glutamine, and $50 \mu \mathrm{g} / \mathrm{mL}$ gentamycin at $37{ }^{\circ} \mathrm{C}$ with $5 \% \mathrm{CO}_{2}$. In addition, concanavalin A (ConA, Sigma Chemical Co. St Louis, MO, USA) was used as a mitogen to trigger cell division in T-lymphocytes. ConA $(10 \mu \mathrm{g} / \mathrm{mL})$ was added at the beginning of the culture, and after $24 \mathrm{~h}$, the cells were treated with the test drugs.

For all experiments, cell viability was examined using Trypan blue exclusion assays. Over $90 \%$ of the cells were viable at the beginning of the culture.

\section{Cytotoxicity assay}

Cell viability was quantified using alamar blue assay, as previously described [8]. For all experiments, cells were seeded in 96-well plates $\left(0.7 \times 10^{5}\right.$ cells $/ \mathrm{mL}$ for adherent cells or $0.3 \times 10^{6}$ cells $/ \mathrm{mL}$ for suspended cells in $100 \mu \mathrm{L}$ of medium). After $24 \mathrm{~h}$ (or immediately for the suspended cells), the samples, which were dissolved in dimethyl sulfoxide (DMSO, Sigma-Aldrich, St Louis, $\mathrm{MO}$, USA) at a final concentration of $50 \mu \mathrm{g} / \mathrm{mL}$, were added to each well and incubated for $72 \mathrm{~h}$. Doxorubicin (purity $>95 \%$, Laboratórios IMA S.A.I.C., Buenos Aires, Argentina) was used as the positive control. The negative control received the vehicle used to dilute the tested samples $(0.5 \%$ DMSO). Four (for cell lines) or $24 \mathrm{~h}$ (for PBMC) before the end of the incubation, $20 \mu \mathrm{L}$ of stock solution $(0.312 \mathrm{mg} / \mathrm{mL})$ of the alamar blue (resazurin, Sigma-Aldrich, St Louis, MO, USA) were added to each well. The absorbance was measured using a SpectraMax 190 microplate reader (Molecular Devices, Sunnyvale, USA), and the drug effect was quantified as the percentage of control absorbance at 570 and $600 \mathrm{~nm}$. The extracts that caused more than $75 \%$ cell growth inhibition were tested again at concentrations varying from 0.39 to $50 \mu \mathrm{g} / \mathrm{mL}$ to determine the $50 \%$ inhibitory concentration $\left(\mathrm{IC}_{50}\right)$. Isolated compounds were tested at concentrations varying from 0.19 to $25 \mu \mathrm{g} / \mathrm{mL}$.

\section{Statistical analysis}

Data are presented as the mean \pm S.E.M. The $\mathrm{IC}_{50}$ values were obtained through nonlinear regression using the GraphPad program (Intuitive Software for Science, San Diego, USA).

\section{Results and discussion}

Fifty-five extracts were obtained from the plants studied, and their cytotoxicities were tested using the alamar blue assay after $72 \mathrm{~h}$ of incubation. The cytotoxicity of each 
extract was initially tested against two tumor cell lines (HepG2 and HL-60) at a final concentration of $50 \mu \mathrm{g} / \mathrm{mL}$. The plant species and plant parts/solvent used for extract preparation are shown in Table 2 . Concentration-response curves were generated and $\mathrm{IC}_{50}$ values were calculated against four tumor cell lines (B16-F10, HepG2, K562 and HL-60) and against one non-tumor cells (PBMC) for the extracts that caused more than $75 \%$ cell growth inhibition (Table 3). In addition, the chloroform soluble fractions of $D$. repens flowers and the hexane extract $I$. coccinea flowers isolated quercetin and the mixture of $\alpha$ - and $\beta$-amyrin (Fig. 1), respectively, which were also tested for their cytotoxic activity (Table 3 ).

Table $3 I_{50}$ values of plant extracts/fractions and isolated compounds against tumor cell lines

\begin{tabular}{|c|c|c|c|c|c|c|c|}
\hline \multirow[t]{2}{*}{ No. } & \multirow[t]{2}{*}{ Plant species } & \multirow{2}{*}{$\begin{array}{l}\text { Parts of plant } \\
\text { (Extractions }^{b} \text { ) }\end{array}$} & \multicolumn{5}{|c|}{ Cells $^{c}\left({ }^{\prime} C_{50} \text { in } \mu \mathrm{g} / \mathrm{mL}\right)^{d}$} \\
\hline & & & B16-F10 & HepG2 & HL60 & K562 & PBMC \\
\hline \multirow[t]{2}{*}{04} & Byrsonima sericea DC. & $\mathrm{L}(\mathrm{m} / \mathrm{e})$ & 13.46 & 27.95 & 32.56 & $>50$ & 33.81 \\
\hline & & & $10.47-17.30$ & $20.79-37.60$ & $25.44-41.66$ & & $26.45-43.23$ \\
\hline \multirow[t]{2}{*}{05} & & L (ea/e) & 17.44 & 41.53 & 28.21 & $>50$ & $>50$ \\
\hline & & & $13.95-21.81$ & $35.31-48.85$ & $21.18-37.57$ & & \\
\hline \multirow[t]{2}{*}{07} & & $\mathrm{~L}(\mathrm{~h} / \mathrm{e})$ & 16.89 & 26.19 & 16.14 & 28.32 & 17.58 \\
\hline & & & $14.63-19.49$ & $23.14-29.64$ & $13.85-18.82$ & $16.96-47.29$ & $10.01-30.86$ \\
\hline \multirow[t]{2}{*}{11} & Duranta repens Linn. & $L(c / e)$ & 29.00 & 33.78 & 22.41 & 21.12 & $>50$ \\
\hline & & & $24.51-34.30$ & $29.44-38.75$ & $14.10-35.62$ & $17.77-25.11$ & \\
\hline \multirow[t]{2}{*}{56} & Quercetin & - & 12.12 & 12.15 & 8.81 & 14.93 & 14.39 \\
\hline & & & $9.92-14.81$ & $9.82-15.05$ & $7.28-10.65$ & $13.90-16.04$ & $11.18-18.52$ \\
\hline \multirow[t]{2}{*}{19} & Himatanthus bracteatus (A.DC.) Woodson & $L(c / e)$ & 22.43 & 24.75 & 23.06 & 29.85 & 12.53 \\
\hline & & & $20.80-24.18$ & $21.70-28.22$ & $20.62-25.79$ & $26.87-33.15$ & $8.28-18.96$ \\
\hline \multirow[t]{2}{*}{20} & Ipomoea purga (Wender.) Hayne & $S(e)$ & 7.39 & 8.52 & 9.39 & 8.53 & 6.99 \\
\hline & & & $6.03-9.07$ & $7.51-9.65$ & $7.81-11.30$ & $7.61-9.56$ & $4.43-11.02$ \\
\hline \multirow[t]{2}{*}{21} & & $L(e)$ & 16.30 & 29.63 & 32.64 & 28.95 & 30.71 \\
\hline & & & $11.80-22.51$ & $25.59-34.31$ & $28.15-37.85$ & $24.39-34.36$ & $24.04-39.24$ \\
\hline \multirow[t]{2}{*}{28} & Ixora coccinea Linn. & $F(c / e)$ & 40.41 & 38.25 & 36.92 & $>50$ & $>50$ \\
\hline & & & $36.60-44.63$ & $30.46-48.04$ & $33.52-40.67$ & & \\
\hline \multirow[t]{2}{*}{57} & Mixture of $a$ - and $\beta$-amyrin & - & 23.21 & 24.09 & $>25$ & $>25$ & $\mathrm{Nd}$ \\
\hline & & & $18.51-29.11$ & $18.71-31.01$ & & & \\
\hline \multirow[t]{2}{*}{29} & Mabea piriri Aubl. & $S(e)$ & 17.76 & 32.98 & 22.72 & 21.89 & $>50$ \\
\hline & & & $13.42-23.51$ & $27.61-39.40$ & $13.26-38.91$ & $15.52-30.87$ & \\
\hline \multirow[t]{2}{*}{37} & Ocotea longifolia Kunth (Oreodaphne opifera Mart. Nees) & $L(e)$ & 37.07 & 37.34 & 31.00 & 43.34 & 21.06 \\
\hline & & & $32.10-42.81$ & $31.34-44.49$ & $21.04-45.69$ & $39.47-47.58$ & $17.48-25.37$ \\
\hline \multirow[t]{2}{*}{43} & Psychotria capitata Ruiz \& Pav. & L (ea/e) & 15.58 & 18.32 & 18.91 & 31.38 & 12.73 \\
\hline & & & $11.29-21.51$ & $14.91-22.50$ & $13.93-25.67$ & $22.78-43.22$ & $7.43-21.81$ \\
\hline \multirow[t]{4}{*}{44} & & $L(c / e)$ & 27.06 & 37.06 & 36.06 & 16.45 & 29.14 \\
\hline & & & $19.26-38.02$ & $31.54-43.53$ & $28.65-45.40$ & $13.16-20.56$ & $22.46-37.82$ \\
\hline & Doxorubicin $^{e}$ & & 0.08 & 0.03 & 0.02 & 0.06 & 0.14 \\
\hline & & & $0.06-0.11$ & $0.02-0.03$ & $0.02-0.02$ & $0.04-0.09$ & $0.02-1.08$ \\
\hline
\end{tabular}

Nd Not determined

${ }^{a}$ Parts of the plant: $L$ leaves, $S$ stem, and $F$ Fruits

bxtractions: $h$ hexane, $m$ methanol, $e$ ethanol, $m / e$ methanol/ $\mathrm{H}_{2} \mathrm{O}$ partition from the ethanolic extract, ea/e ethyl acetate partition from the ethanolic extract, $h / e$ hexane partition from the ethanolic extract, c/e chloroform partition from the ethanolic extract, $h: e a / e$ hexane:ethyl acetate (1:1) partition from the ethanolic extract

'Tumor cells: B16-F10 (mouse melanoma), HepG2 (human hepatocellular carcinoma), HL-60 (human promyelocytic leukemia) and K562 (human chronic myelocytic leukemia). Non-tumor cells: PBMC (human peripheral blood mononuclear cells activated with concanavalin A - human lymphoblast)

${ }^{\mathrm{d}}$ Data are presented as $\mathrm{IC}_{50}$ values in $\mu \mathrm{g} / \mathrm{mL}$ and their $95 \%$ confidence interval obtained by nonlinear regression from three independent experiments performed in duplicate, measured using alamar blue assay after $72 \mathrm{~h}$ incubation. The negative control received the vehicle used to dilute the tested samples (0.5 \% DMSO)

eDoxorubicin was used as the positive control 
<smiles>O=c1c(O)c(-c2ccc(O)c(O)c2)oc2cc(O)cc(O)c12</smiles>

56
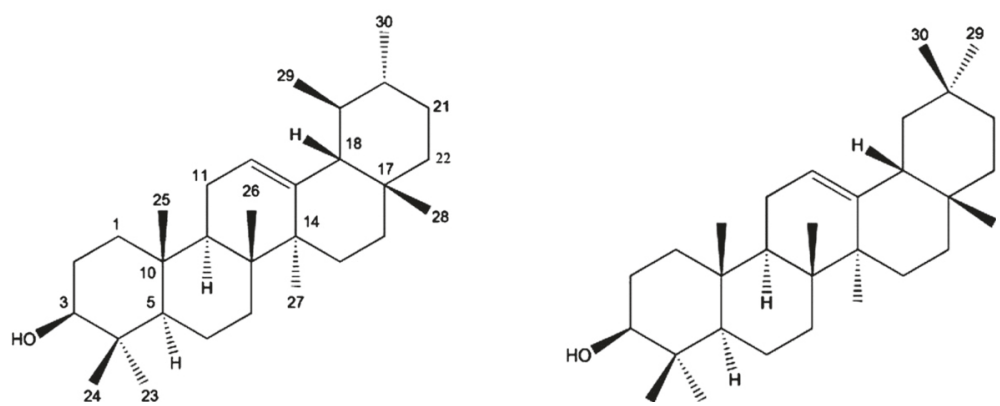

57

Fig 1 The chemical structures of quercetin (56) isolated from the chloroform soluble fractions of Duranta repens flowers and a- and $\beta$-amyrin (57) isolated from the hexane extract of Ixora coccinea flowers

In the preclinical cytotoxic drug screening program used in this work, which is based in the United States National Cancer Institute program, only those extracts that present $\mathrm{IC}_{50}$ values below $30 \mu \mathrm{g} / \mathrm{mL}$ and pure compounds with $\mathrm{IC}_{50}$ values below $4 \mu \mathrm{g} / \mathrm{mL}$ in tumor cell line assays are considered to be promising for anticancer drug development [9-11]. Therefore, the B. sericea, $D$. repens, $H$. bracteatus, I. purga, I. coccinea, M. piriri, $O$. longifolia and $P$. capitata extracts demonstrated promising cytotoxic activity. Doxorubicin, a clinical useful chemotherapy drug, was used as the positive control and presented $\mathrm{IC}_{50}$ values ranged from 0.02 to $0.08 \mu \mathrm{g} / \mathrm{mL}$ for $\mathrm{HL}-60$ and B16-F10, respectively.

The pharmacology activity of $B$. sericea has been previously reported; the ethanolic extract from its leaves has gastroprotective properties that are mediated by nitric oxide and the $\mathrm{K}^{+}$ATP channel. Phytochemical studies have revealed the presence of flavonoids (i.e., rutin, isoquercitrin, kaempferol 3-O-rutinoside and quercetin). However, its cytotoxic activity has not been previously reported [12]. Previous studies of D. repens have reported the presence of triterpenes, flavonoids, steroids, $C$-alkylated flavonoids and acetosides, as well as some alkaloids. Interestingly, durantanin IV and $\mathrm{V}$ and $E / Z$ acteoside isolated from the leaves of $D$. repens have demonstrated significant cytotoxic activity against a HepG2 cell line [13]. Jalapinoside, a macrocyclic bisdesmoside resin glycoside, was recently isolated from the roots of $I$. purga, and its cytotoxic activity was evaluated. Jalapinoside was not cytotoxic $\left(\mathrm{IC}_{50}>10 \mu \mathrm{g} / \mathrm{mL}\right)$, but reversal of multidrug resistance was observed using vinblastineresistant human breast carcinoma cells [14]. In this study, we isolated the flavonol quercetin from the flowers of $D$. repens, which demonstrated a cytotoxic effect (with $\mathrm{IC}_{50}$ values ranging from 8.81 to $14.93 \mu \mathrm{g} / \mathrm{mL}$ on tumor cell lines HL-60 and K562, respectively). Quercetin has been previously reported as a cytotoxic agent because of its ability to induce apoptosis $[15,16]$.

The antitumor activity of flowers of I. coccinea was previously studied in murine models. Inhibited tumor growth and increased life spans were observed in Dalton's lymphoma and Ehrlich ascites carcinoma-bearing mice [17]. Moreover, ixorapeptide I, a peptide derived from I. coccinea, displayed cytotoxicity against the Hep3B liver tumor cell line, with an $\mathrm{IC}_{50}$ value of $3.36 \mu \mathrm{g} / \mathrm{mL}$ [18]. Interestedly, although the use of $I$. coccinea is currently only ornamental in Brazil, its flowers are an ingredient in an Ayurvedic cancer formulation in India $[19,20]$. The flowers of I. coccinea are used to treat cancer, leucorrhoea, dysentery, dysmenorrhea, hemoptysis and hypertension; its leaves are used to pacify vitiated pitta, skin diseases, colic, flatulence, diarrhea, indigestion, ulcers and wounds, and they are also used as an antiseptic [20,21]. The roots of I. coccinea are used as an astringent and antiseptic against scabies and other skin 
diseases [20]. In this study, the fractionation of the extract of $I$. coccinea flowers resulted in the mixture of $\alpha$ - and $\beta$ amyrin, which demonstrated weak cytotoxic activity toward tumor cell lines. In fact, no potent cytotoxic activity has been reported for these compounds.

Prieto et al. [22] have reported that essential oil from the leaves of $O$. longifolia, of which $\alpha$-terpinolene and $\alpha$ phellandrene are the primary ingredients, demonstrates antifungal activity against Sitophilus zeamais. However, the cytotoxic activity of the O. longifolia plant has not been previously reported. No previous biological effects have been reported for the medicinal plants H. bracteatus, M. piriri and P. capitata.

The extracts from $C$. impressinervia, $H$. tomentosa, $M$. minutiflora, M. charantia, O. glomerata, P. fruticosa, S. morototoni, S. paludosum, X. frutescens and Z. rhoifolium showed no pronounced cytotoxic effects. Among these plants, essential oil from the leaves of $X$. frutescens has been previously assessed for its cytotoxic and antitumor effects; the oil demonstrated potent in vitro cytotoxic activity against tumor cell lines from different histotypes and in vivo antitumor activity in sarcoma 180 murine model [23]. Although essential oil from $Z$. rhoifolium leaves and $M$. charantia fruit extract have been previously assessed for cytotoxicity, they demonstrated no cytotoxic effects $[24,25]$. The cytotoxic potential of C. impressinervia, H. tomentosa, M. minutiflora, O. glomerata, P. fruticose, S. morototoni and S. paludosum plants has never been investigated.

\section{Conclusion}

In conclusion, we screened the cytotoxic potential of 55 extracts from 18 plants found in northeast Brazil, and extracts from $B$. sericea, $D$. repens, $H$. bracteatus, $I$. purga, I. coccinea, M. piriri, O. longifolia and P. capitata demonstrated potent cytotoxic effects. The fractionation of $D$. repens and $I$. coccinea extracts led to the isolation of quercetin and the mixture of $\alpha$ - and $\beta$-amyrin, respectively, and quercetin showed moderate cytotoxic activity. Fractionation of the other plants should be performed to identify their active constituents, and further investigations are required to determine their mechanisms of cytotoxicity and in vivo activities. This work reinforces the need to understand the therapeutic potentialities of Brazilian medicinal plants.

\footnotetext{
Abbreviations

CC, column chromatography; ConA, concanavalin A; DMSO, dimethyl sulfoxide; IC $C_{50}, 50$ \% inhibitory concentration; NMR, nuclear magnetic resonance; PBMC, peripheral blood mononuclear cells; RPMI-1640, roswell park memorial institute-1640; TLC, thin layer chromatography; TMS, tetramethylsilane
}

\section{Acknowledgments}

The authors are grateful to Edileuza Soares Passos for providing technical assistance and to Rosângela Pereira e Lyra Lemos of the IMA-AL for providing the botanical identifications.

\section{Funding}

This work was financially supported by the following Brazilian agencies: CAPES (Coordenação de Aperfeiçoamento de Pessoal de Nível Superior), CNPq (Conselho Nacional de Desenvolvimento Cientifico e Tecnológico) and FAPESB (Fundação de Amparo à Pesquisa e à Inovação Tecnológica do Estado da Bahia).

\section{Availability of data and materials}

We have presented our primary data in the form of figure and tables. The datasets supporting the conclusions of this article are included within the article.

\section{Authors' contributions \\ Conceived and designed the experiments: TBCS, MBPS and DPB. Performed the experiments: CODC, AFCG, LMB, ACBCR, MCSM, AAD and TRS. Analyzed the data: TBCS and DPB. Contributed the reagents/materials/analysis tools: TBCS, MBPS and DPB. Wrote the paper: TBCS, MBPS and DPB. All authors read and approved the final manuscript for submission.}

\section{Competing interests}

The authors declare that they have no competing interests.

\section{Consent for publication}

All study participants provided informed consent for the data publication.

\section{Ethics approval and consent to participate}

For the PBMC collection, the Research Ethics Committee of the Oswaldo Cruz Foundation (Salvador, Bahia, Brazil) approved the experimental protocol (number 031019/2013). All participants provided written informed consent to participate in the study.

\section{Author details}

'Undade de Ensino de Viçosa, Campus Arapiraca, Universidade Federal de Alagoas, Viçosa, Alagoas, Brazil. ${ }^{2}$ Instituto Gonçalo Moniz, Fundação Oswaldo Cruz (IGM/FIOCRUZ-BA), Rua Waldemar Falcão, 121, Candeal, 40296-710

Salvador, Bahia, Brazil. ${ }^{3}$ Centro de Biotecnologia e Terapia Celular, Hospital São Rafael, Salvador, Bahia, Brazil.

Received: 7 April 2016 Accepted: 22 June 2016

Published online: 08 July 2016

\section{References}

1. Lewinsohn TL, Prado PI. Quantas espécies há no Brasil? Megadiversidade. 2005;1(1):36-42

2. Melo JG, Santos AG, Amorim ELC, Nascimento SC, Albuquerque UP. Medicinal plants used as antitumor agents in Brazil: an ethnobotanical approach. Evid Based Complement Alternat Med. 2011;2011:365359.

3. Forzza RC, Baumgratz JFA, Bicudo CEM, Canhos DAL, Carvalho Jr AA, Coelho MAN, et al. New brazilian floristic list highlights conservation challenges. Bioscience. 2012;62(1):39-45.

4. Mesquita ML, de Paula JE, Pessoa C, de Moraes MO, Costa-Lotufo LV, Grougnet R, et al. Cytotoxic activity of Brazilian Cerrado plants used in traditional medicine against cancer cell lines. J Ethnopharmacol. 2009; 123(3):439-45.

5. Ozi JM, Suffredini IB, Paciencia M, Frana SA, Dib LL. In vitro cytotoxic effects of Brazilian plant extracts on squamous cell carcinoma of the oral cavity. Braz Oral Res. 2011;25(6):519-25.

6. Ferreira PM, Farias DF, Viana MP, Souza TM, Vasconcelos IM, Soares BM, et al. Study of the antiproliferative potential of seed extracts from Northeastern Brazilian plants. An Acad Bras Cienc. 2011;83(3):1045-58.

7. Ribeiro SS, de Jesus AM, dos Anjos CS, da Silva TB, Santos AD, de Jesus JR, et al. Evaluation of the cytotoxic activity of some Brazilian medicinal plants. Planta Med. 2012;78(14):1601-6.

8. Ahmed SA, Gogal RM, Walsh JE. A new rapid and simple non-radioactive assay to monitor and determine the proliferation of lymphocytes an alternative to $\left[{ }^{3} \mathrm{H}\right.$ ] thymidine incorporation assay. J Immunol Methods. 1994; 170(2):211-24.

9. Suffness M, Pezzuto JM. Assays related to cancer drug discovery. In: Hostettmann K, editor. Methods in plant biochemistry: assays for bioactivity. London: Academic Press; 1990. p. 71-133. 
10. Quintans JSS, Soares BM, Ferraz RPC, Oliveira ACA, Silva TB, Menezes LRA, et al. Chemical constituents and anticancer effects of the essential oil from leaves of Xylopia laevigata. Planta Med. 2013;79(2):123-30.

11. Rodrigues ACBC, Bomfim LM, Neves SP, Menezes LRA, Dias RB, Soares MBP, et al. Antitumor properties of the essential oil from the leaves of Duguetia gardneriana. Planta Med. 2015;81(10):798-803.

12. Rodrigues PA, Morais SM, Souza CM, Magalhaes DV, Vieira IGP, Andrade GM, et al. Gastroprotective effect of Byrsonima sericea DC leaf extract against ethanol-induced gastric injury and its possible mechanisms of action. An Acad Bras Cienc. 2012;84(1):113-22.

13. Ahmed WS, Mohamed MA, El-Dib RA, Hamed MM. New triterpene saponins from Duranta repens Linn. and their cytotoxic activity. Molecules. 2009;14(5):1952-65.

14. Bautista E, Fragoso-Serrano M, Pereda-Miranda R. Jalapinoside, a macrocyclic bisdesmoside from the resin glycosides of Ipomea purga, as a modulator of multidrug resistance in human cancer cells. J Nat Prod. 2015;78(1):168-72.

15. Siegelin MD, Reuss DE, Habel A, Rami A, von Deimling A. Quercetin promotes degradation of survivin and thereby enhances death-receptormediated apoptosis in glioma cells. Neuro Oncol. 2009;11(2):122-31.

16. Jakubowicz-Gil J, Langner E, Bądziul D, Wertel I, Rzeski W. Apoptosis induction in human glioblastoma multiforme T98G cells upon temozolomide and quercetin treatment. Tumour Biol. 2013;34(4):2367-78.

17. Latha PG, Panikkar KR. Cytotoxic and antitumor principles from Ixord coccinea flowers. Cancer Lett. 1998;130(1-2):197-202.

18. Lee CL, Liao YC, Hwang TL, Wu CC, Chang FR, Wu YC. Ixorapeptide I and ixorapeptide II, bioactive peptides isolated from Ixora coccinea. Bioorg Med Chem Lett. 2010;20(24):7354-7.

19. Panikkar KR, Bhanumathy P, Raghunath PN. Antitumour activity of an ayurvedic oil preparation. Ancient Sci Life. 1986;6(2):107-8.

20. Kharat AR, Nambiar W, Tarkasband YS, Pujari RR. A review on phytochemical and pharmacological activity of genus /xora. IJRPC. 2013;3(3):628-35.

21. John D. One hundred useful raw drugs of Kani tribes of trivandrum forest division, Kerala, India. Int J Crude Drug Res. 1984;22(1):17-39.

22. Prieto JA, Pabon LC, Patino OJ, Delgado WA, Cuca LE. Chemical constituents and insecticidal and antifungal activities of the essential oils of leaves of two Colombian species of the genus Ocotea (Lauraceae). Rev Colomb Quim. 2010:39(2):199-209.

23. Ferraz RP, Cardoso GM, da Silva TB, Fontes JE, Prata AP, Carvalho AA, et al. Antitumour properties of the leaf essential oil of Xylopia frutescens Aubl. (Annonaceae). Food Chem. 2013;141(1):196-200.

24. Masuda T, Oyama Y, Yamamoto N, Umebayashi C, Nakao H, Toi Y, et al. Cytotoxic screening of medicinal and edible plants in Okinawa, Japan, and identification of the main toxicconstituent of Rhodea japonica (Omoto). Biosci Biotechnol Biochem. 2003:67(6):1401-4.

25. Boehme AK, Noletto JA, Haber WA, Setzer WN. Bioactivity and chemical composition of the leaf essential oils of Zanthoxylum rhoifolium and Zanthoxylum setulosum from Monteverde, Costa Rica. Nat Prod Res. 2008;22(1):31-6.

26. Agra MF, Freitas PF, Barbosa-Filho JM. Synopsis of the plants known as medicinal and poisonous in Northeast of Brazil. Braz J Pharmacog. 2007;17(1):114-40.

27. Amaral GC, Brito LPS, Avelino RC, Silva Júnior JV, Beckmann-Cavalcante MZ, Cavalcante IHL. Seedlings production of Duranta repens I. using cuttings process. Rev Ciênc Agrár. 2012;35(1):134-42.

28. Costa LCB, Rocha EA, Silva LAM, Jardim JG, Silva DC, Gaião LO, et al. Levantamento preliminar das espécies vegetais com potencial econômico no parque municipal da Boa Esperança, Ilhéus, Bahia, Brasil. Acta Farm Bonaerense. 2006;25(2):184-91.

29. Madaleno IM. Popular medicinal plants from São Luis, Brazil. Bol Mus Para Emílio Goeldi Cienc Hum. 2011;6(2):273-86.

30. Siviero A, Delunardo TA, Haverroth M, Oliveira LC, Roman ALC, Mendonça AMS. Ornamental plants in urban homegardens of Rio Branco, Brazil. Bol Mus Para Emílio Goeldi Cienc Hum. 2014:9(3):797-813.

31. Martins JEC. Plantas medicinais de uso na amazônia. 2nd ed. São Paulo: Graficentro-CEJUP; 1989.

32. De Paula JE, Alves JLH. Madeiras naturais: anatomia, dendrologia, dendrometria, produção e uso. Brasília: Fundação Mokiti Okada-MOA; 1997.

33. Breitbach UB, Niehues M, Lopes NP, Faria JEQ, Brandão MGL. Amazonian Brazilian medicinal plants described by C.F.P. von Martius in the 19th century. J Ethnopharmacol. 2013;147(1):180-9.

34. Cruz GL. Dicionário de plantas úteis do Brasil. In: Bertrand Brasil. 5th ed. Rio de janeiro; 1995. p. 436

\section{Submit your next manuscript to BioMed Central and we will help you at every step:}

- We accept pre-submission inquiries

- Our selector tool helps you to find the most relevant journal

- We provide round the clock customer support

- Convenient online submission

- Thorough peer review

- Inclusion in PubMed and all major indexing services

- Maximum visibility for your research

Submit your manuscript at www.biomedcentral.com/submit
Biomed Central 